\title{
ZOOCHORY AND PECULIARITIES OF FOREST COMMUNITY FORMATION: A REVIEW
}

\author{
O. I. Evstigneev \\ Bryansky Les State Nature Reserve, Nerussa Station, the Bryansk Region, 242180, Russia \\ E-mail: quercuseo@mail.ru
}

\section{N. Korotkov}

Lomonosov Moscow State University, 1 Leninskiye gory, Moscow, 119991, Russia

E-mail:korotkovv@list.ru

\section{A. Murashev}

Scientific and Research Zoological Museum of Lomonosov Moscow State University, 6 Bolshaya Nikitskaya, Moscow, 125009, Russia E-mail: ilyamurashev@gmail.com

\section{P. V. Voevodin}

Nonprofit organization 'Verkhovye Nature Conservation Fund', 6 Agrokhimikov, Odintsovo district, the Moscow Regon, 143026, Russia E-mail:voevodin_p@mail.ru

\section{ЗООХОРИЯ И ОСОБЕННОСТИ ФОРМИРОВАНИЯ ЛЕСНЫХ СООБЩЕСТВ: ОБЗОР}

\section{О. И. Евстигнеев}

Заповедник «Брянский лес», Россия, 242180, Брянская область, Нерусса

E-mail:quercus_eo@mail.ru

\section{В. Н. Коротков}

Московский государственный университет имени М. В. Ломоносова, Россия, 119991, Москва, Ленинские горы, 1 E-mail: korotkovv@list.ru

\section{И. А. Мурашев}

Научно-исследовательский Зоологический музей МгУ имени М. В. Ломоносова, Россия, 125009, Москва, ул. Большая Никитская, 6

E-mail: ilyamurashev@gmail.com

\section{П. В. Воеводин}

Некоммерческая организация Природоохранный фонд «Верховье», Россия, 143026, Московская область, Одинцовский район, ул. Агрохимиков, 6 E-mail:voevodin_p@mail.ru

Abstract. Based on the analysis of the literature on the home range of animals, information on the distances of diaspore dispersals by animals is provided for plants of coniferous-broadleaved forests. Mass and moderate dispersals of diaspores are important for formation of plant communities. Diaspores are moved in mass quantities within the diurnal areas of animals and in moderate quantities within the borders of seasonal areas. A continuous series is built on the range of mass dissemination of plant diaspores by animals, from tens of metres (small rodents) to one kilometre (large mammals). In coniferous-broadleaved forests three groups of plant species have been distinguished on adaptation to diaspore dispersals by animals. The first group includes plants with juicy fruits (e.g., Malus sylvestris, Sorbus aucuparia, Vaccinium myrtillus). A wide range of animals disperse diaspores of these plants at a distance of $20 \mathrm{~m}$ to 1,000 $\mathrm{m}$, mainly in the endozoochoric way. The second group includes plants with large and dry seeds (e.g., Corylus avellana, Fraxinus excelsior, Quercus robur). The seeds of these plants are dispersed by animals that stock seeds at a distance of up to $500 \mathrm{~m}$ in the synzoochoric way. The third group includes plants with small and dry diaspores (e.g., Aegopodium podagraria, Melica nutans, Stellaria holostea et. all). Their seeds can be moved by large birds, bears, ungulates in the endozoochoric way in large quantities at a distance of up to $1,000 \mathrm{~m}$. Due to the extremely low number of those animals, plants with small and dry seeds have lost inter- 
cenotic diaspore flows that are needed for changes of plant communities and for restoration succession. As a result, subclimax communities with a diminished species composition of plants are formed.

Key words: seed dispersal, diaspores, coniferous-broadleaved forest, zoochory, home range, succession

For citation: Evstigneev O.I., Korotkov V.N., Murashev I.A., Voevodin P.V. Zoochory and peculiarities of forest community formation: a review. Russian Journal of Ecosystem Ecology. 2017;2(1). Available from: https://doi.org/10.21685/2500-0578-2017-1-2

Аннотация. На основе анализа литературы по индивидуальным участкам животных приводятся данные о дальности перемещения семян животными для растений хвойно-широколиственного леса. Для формирования сообществ важны массовое и умеренное перемещение диаспор. Массово диаспоры перемещаются в пределах суточных участков животных, а умеренно - в границах сезонных. Выстраивается непрерывный ряд по дальности массового перемещения диаспор растений животными: от одного десятка метров (мелкие мышевидные грызуны) до одного километра (крупные млекопитающие). В хвойно-широколиственном лесу выделено три группы растений по адаптации диаспор к расселению животными. Первая группа - растения с сочными плодами (например, Malus sylvestris, Sorbus aucuparia, Vaccinium myrtillus). Они характеризуются широким набором животных, которые распространяют их семена эндозоохорным способом на расстояние от 20 до 1000 м. Вторая группа - растения с крупными и сухими плодами (Corylus avellana, Fraxinus excelsior, Quercus robur и др.). Распространители их семян ограничены животными, которые растаскивают семена синзоохорным способом. Дальность массового перемещения диаспор этих видов растений - до 500 м. Третья группа - растения с мелкими и сухими диаспорами (Aegopodium podagraria, Melica nutans, Stellaria holostea и др.). Их семена могут перемещаться крупными птицами, медведем и копытными эндозоохорным способом в массовом количестве на расстояние до 1000 м. Однако из-за чрезвычайно низкой численности этих животных растения с мелкими и сухими семенами лишились межценотических потоков диаспор, которые необходимы для смены растительных сообществ и восстановительных сукцессий. В результате формируются субклимаксные ценозы с обедненным видовым составом растений.

Ключевые слова: распространение семян, диаспоры, хвойно-широколиственные леса, зоохория, индивидуальный участок животных, сукцессия.

\section{Introduction}

The movement of diaspores is the basis of the population life of species and an essential condition for the formation of plant communities during successions [1-3]. Information on the distance of plant diaspore dispersals by different agents (above all, animals) is necessary for the study of successions and forecasts of forest communities development [4-6]. Animals play an active part in ecosystems and determine the species composition of communities by moving diaspores (seeds, fruits, vegetative germs, etc.) [7]. However, scientific publications about direct observation on distances of diaspore dispersals by animals are fragmentary. Information on the dissemination distance for different plant species is necessary to study successions $[8,9]$. A possible solution to this problem is the determination of dissemination distance of zoochoric plant diaspores through the size of the individual areas of animal habitats (dissemination agents). So far, this approach has been only partially implemented in a small number of studies for a few plants $[10,11]$. The tasks of the present study are 1) to assess distances of diaspore dispersals for the complex of forest plant species in connection with the territorial behaviour of animals and 2) to analyse some mechanisms of forest communities formation in connection with zoochory.
The objects of consideration are selected plant species from different layers of coniferousbroadleaved forests of Eastern Europe. The following indigenous vertebrate animals with different sizes of habitat areas were considered as disseminators of seeds: wisent or the European wood bison (Bison bonasus L.), brown bear (Ursus arctos L.), elk (Alces alces L.), roe deer (Capreolus capreolus L.), red squirrel (Sciurus vulgaris L.), yellownecked mouse (Apodemus flavicollis Melchior), common field mouse (A. sylvaticus L.), bank vole (Clethrionomys glareolus Schreb.), wood grouse (Tetrao urogallus L.), European jay (Garrulus glandarius L.), spotted nutcracker (Nucifraga caryocatactes L.), greater spotted woodpecker (Dendrocopos major L.), fieldfare (Turdus pilaris L.), Eurasian nuthatch (Sitta europaea L.), willow tit (Parus montanus Baldenstein), marsh tit (P. palustris L.), and coal tit ( $P$. ater L.). The choice of these animals was not accidental. The most complete information on the size of individual areas and species composition of food plants was found in the literature for these species. The main attention was paid to the summer-autumn home ranges of the animals because most of the diaspores ripen at that time. However, diaspores of some plants continued to disperse throughout the winter and spring, such as Fraxinus excelsior L., Sorbus aucuparia L. and Picea abies (L.) Karst. In this 
case, areas of animal habitats in the autumn-winter and spring periods were analysed. The animal feed plant species were divided into three groups (forest, marsh, and meadow) to determine the characteristics of the food behaviour of animals.

\section{Results and discussion}

The scale of zoochory. It is possible to judge the actual participation of animals of coniferousbroadleaved forests in the propagula dissemination of zoochoric plant species in the following numbers. The number of excrement allocated by one wisent per year is $5,000 \mathrm{~kg}$, by elk $2,200 \mathrm{~kg}$, and by roe deer $400 \mathrm{~kg}[12,13]$. From 500 to 2,500 viable seeds were found in one $\mathrm{kg}$ of excrement of grazing animals [14]. According to these data, excrements of bison of up to 13 million viable propagula per year, excrements of elk of up to 6 million viable propagula per year, and excrements of roe deer of up to 1 million viable propagula per year may be moved. In addition, 4.2 million raspberry seeds come with excrement of thrush (Tur$d u s$ sp.) annually per hectare of forest areas [15]. Squirrels complete 300 pine and 30 spruce cones per day [16]. Apodemus flavicollis and A. sylvaticus stock up 2,200 acorns during the autumn months [17]. Garrulus glandarius moves up 20,000 acorns for storage during an autumn [18], and Nucifraga caryocatactes uses up to 430,000 seeds of Pinus sibirica Du Tour [19]. During the winter and early spring, Dendrocopos major collects 11,000 to 16,000 pine cones, which together contain 300,000 to 450,000 seeds [20]. Parus mon- tanus stores 30,000 seeds during one month of autumn [21], $P$. palustris 17,000 seeds, and $P$. ater 6,000 seeds [22]. These numbers are specific to one individual animal to increase by orders of magnitude if they are converted to the number of the total population that lives in the coniferousbroadleaved forest.

Significant for zoochory features of trophic activity of animals. The following issues of animal activities are important for diaspore dispersals of zoochoric plant species: 1) eating of diaspores and their defecation; 2) storage of diaspores, in which part of the reserve is lost or not used; and 3) treatment of the skin of the trailer and adherent diaspores. Three variants of zoochory are distinguished: endozoochory, synzoochory, and epizoochory. Endozoochory is the dispersal of diaspores that passed through the digestive tract of animals and were then ejected with excrements (Fig. 1-3). Synzoochory is the dispersal of diaspores associated with the movement by animals for the purpose of storage in the pantry or eating in the nests and on forges (e.g., of woodpecker) (Fig. 4-7). Epizoochory is the dispersal of diaspores that hitch or stick to animal bodies (Fig. 8) [7]. The included animal species are divided into two groups. The first group includes wisent, brown bear, elk, roe deer, wood grouse, and fieldfare. They spread diaspores mainly by the endozoochoric and epizoochoric ways. The second group includes red squirrel, mice, bank vole, jay, nutcracker, woodpecker, nuthatch, and tits. They spread diaspores mainly by the synzoochoric way.
Fig. 1. Examples of endozoochoric dispersals of seeds and fruits by brown bear (Ursus arctos) in the Bryansk Forest Nature Reserve: $A$ - Bear excrement with remains of apple fruit (Malus sylvestris Mill)

and seeds of Solomon's seal (Polygonatum multiflorum (L.) All.);

$B$ - Bear excrement with cranberry berries

(Oxycoccus palustris Pers.).

Photos by Elena F. Sitnikova

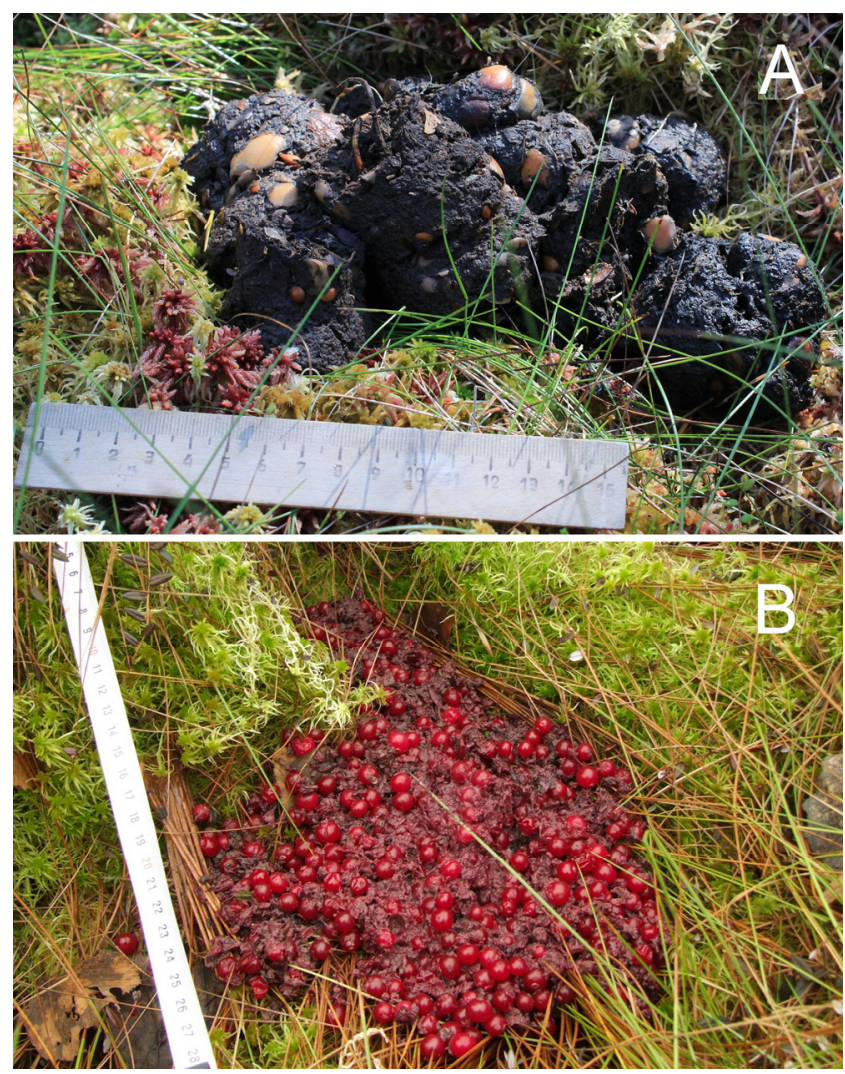



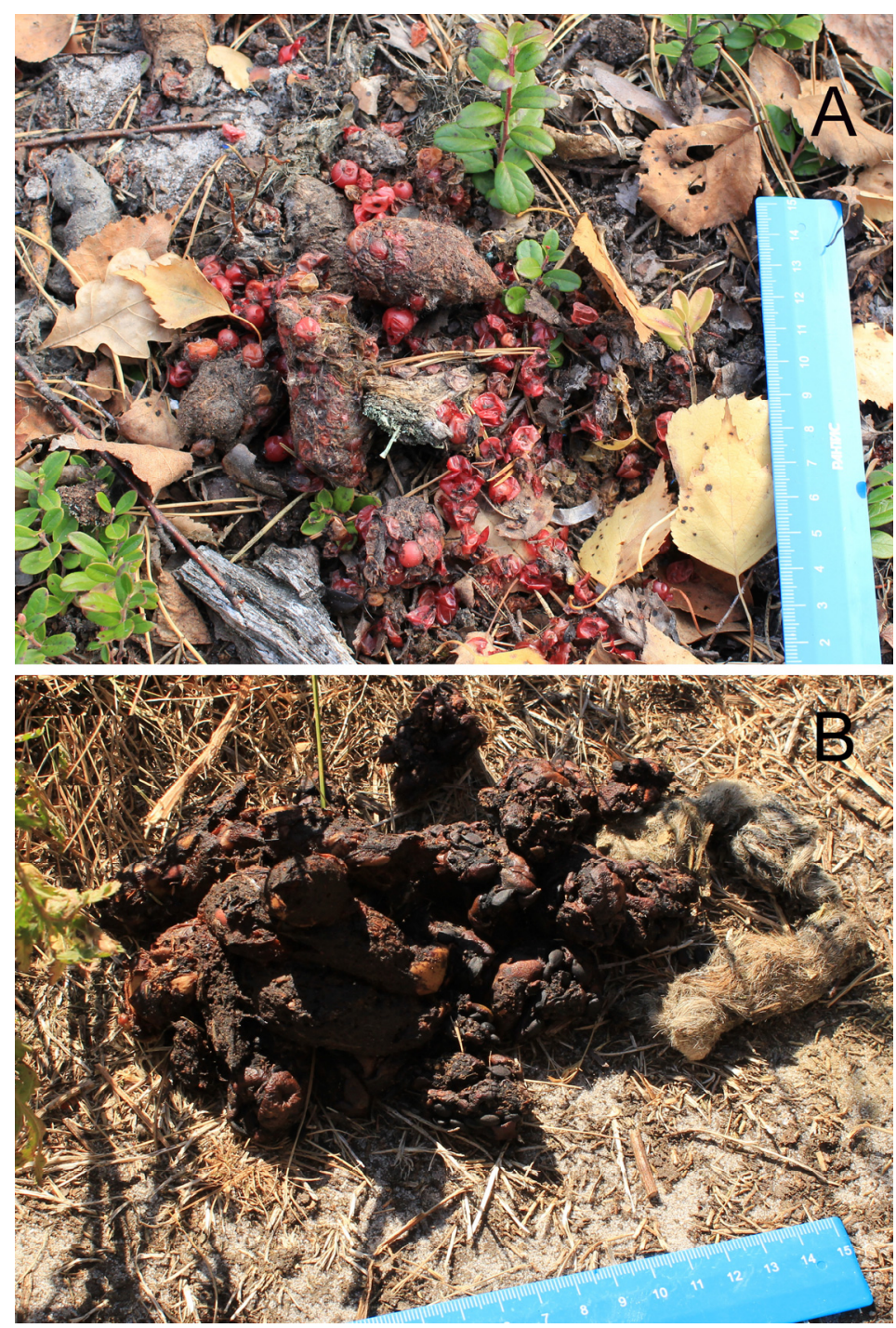

Fig. 2. Examples of endozoochoric dispersals of seeds and fruits by wolf (Canis lupulus L.)

in the Bryansk Forest Nature Reserve: A - Wolf excrement with cowberry (Vaccinium vitis-idaea L.) and seeds of lily-of-the-valley (Convallaria majalis L.);

$B$ - Wolf excrement with seeds and remains of apple fruit (Malus sylvestris) and pears (Pyrus communis L.). Photos by Elena F. Sitnikova

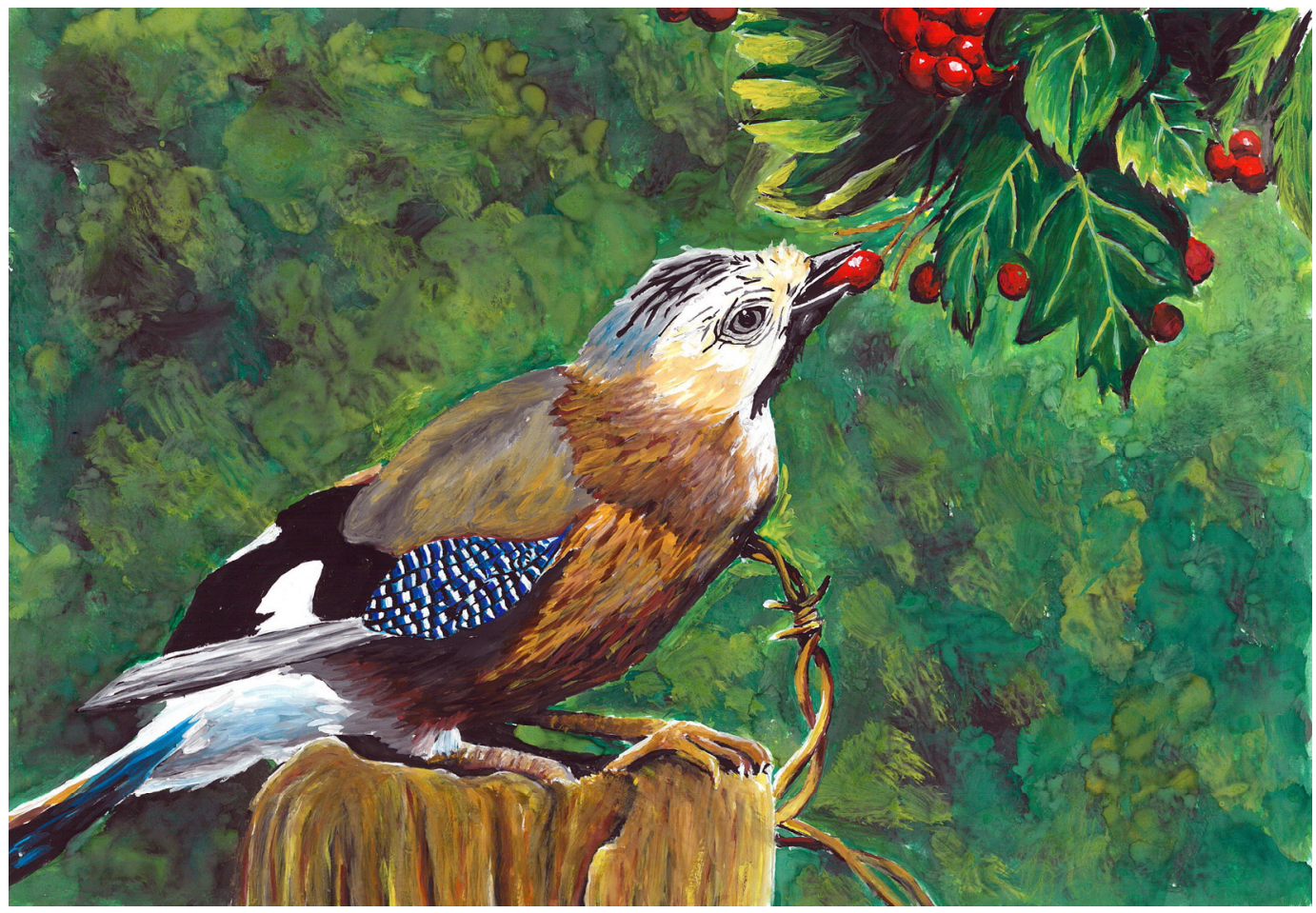

Fig. 3. Example of endozoochoric dispersals of seeds by birds. Jay (Garrulus glandarius) ingests the fruit of a guelder-rose (Viburnum opulus L.). Picture by Alina S. Teslyuk, a schoolgirl (17 years) 
Fig. 4. Examples of synzoochoric dispersals of seeds:

A - Greater spotted woodpecker (Dendrocopos major) carries a spruce cone (Picea abies);

B - Willow tit (Parus montanus) hides a spruce seed (Picea abies) in lichen; C - Jay (Garrulus glandarius) moves an acorn of oak

(Quercus robur L.) in front of expanded part of esophagus and in its beak;

$D$ - Samara of Norway maple (Acer platanoides L.) with eaten embryo;

Eurasian nuthatch

(Sitta europaea) puts samara in the tree bark. Pictures by llya A. Murashev

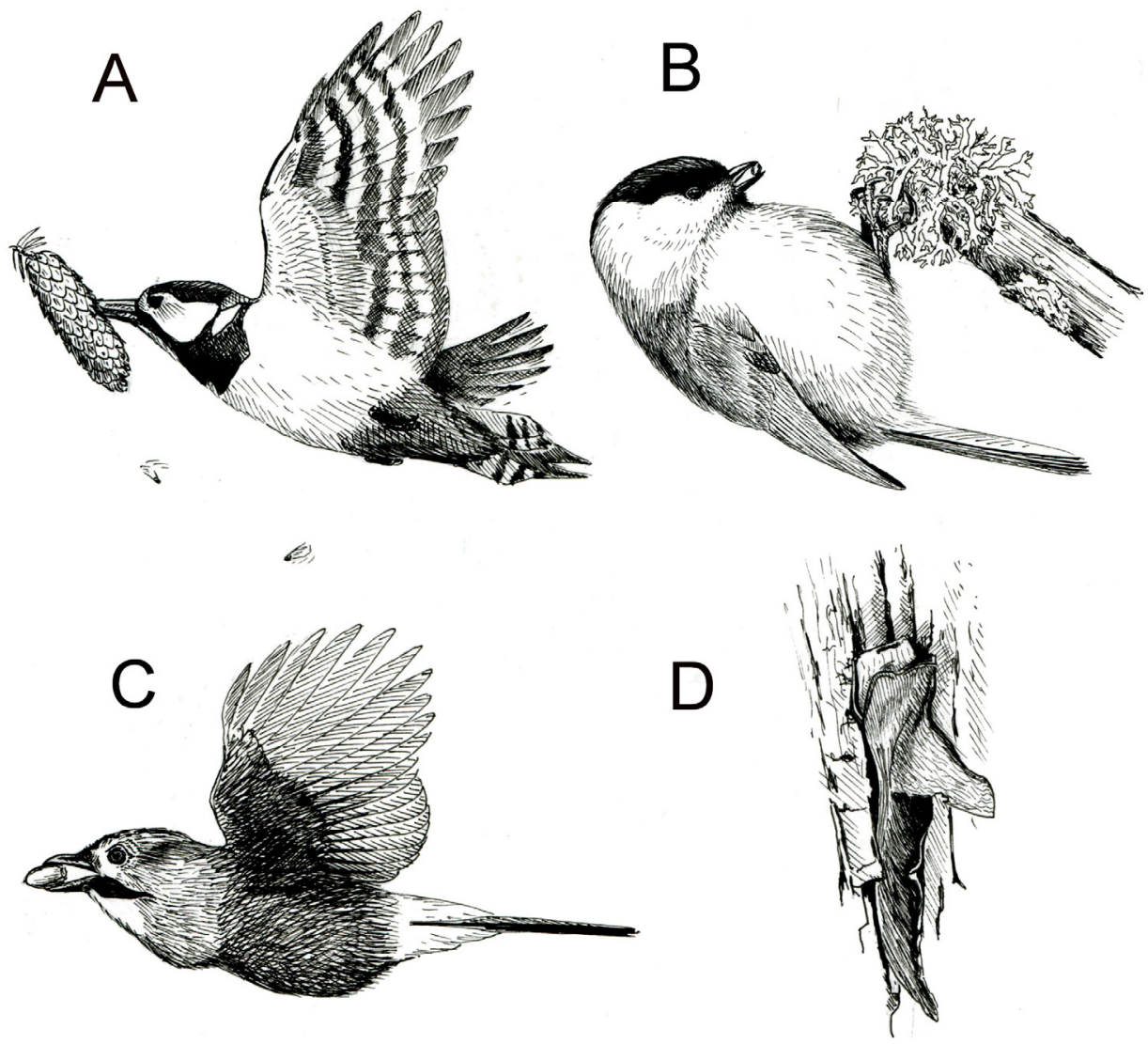

Fig. 5. Examples of synzoochoric dispersals of seeds in the Bryansk Forest Nature Reserve: A - Hazel nuts (Corylus avellana L.) stored and pecked by nuthatch (Sitta europaea) in the bark of oak (Quercus robur). Photo by Olga V. Solonina;

B - Jay (Garrulus glandarius) ingests oak acorn found on gulli of wild boar (Sus scrofa L.). Photo by Alexey V. Gornov
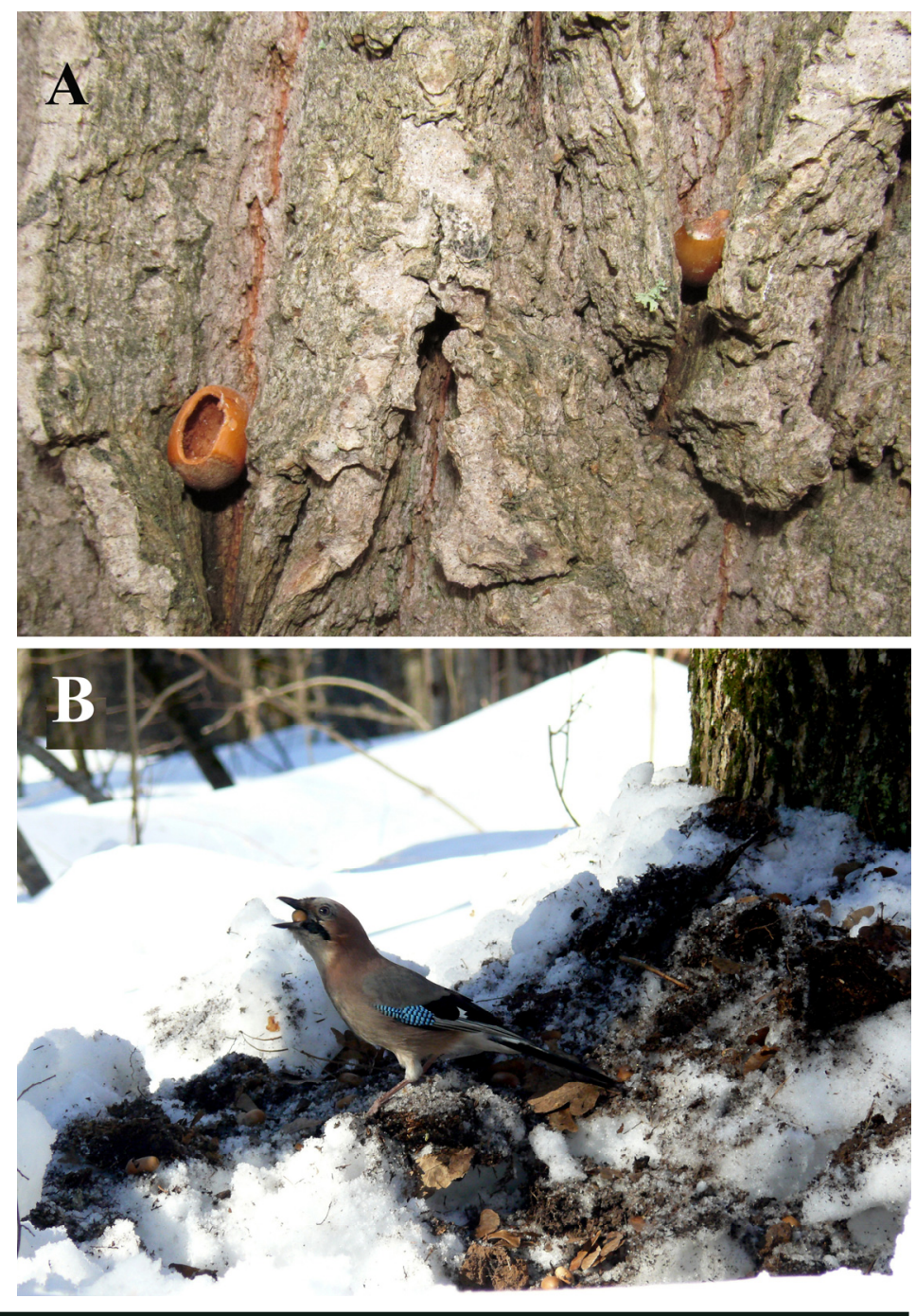


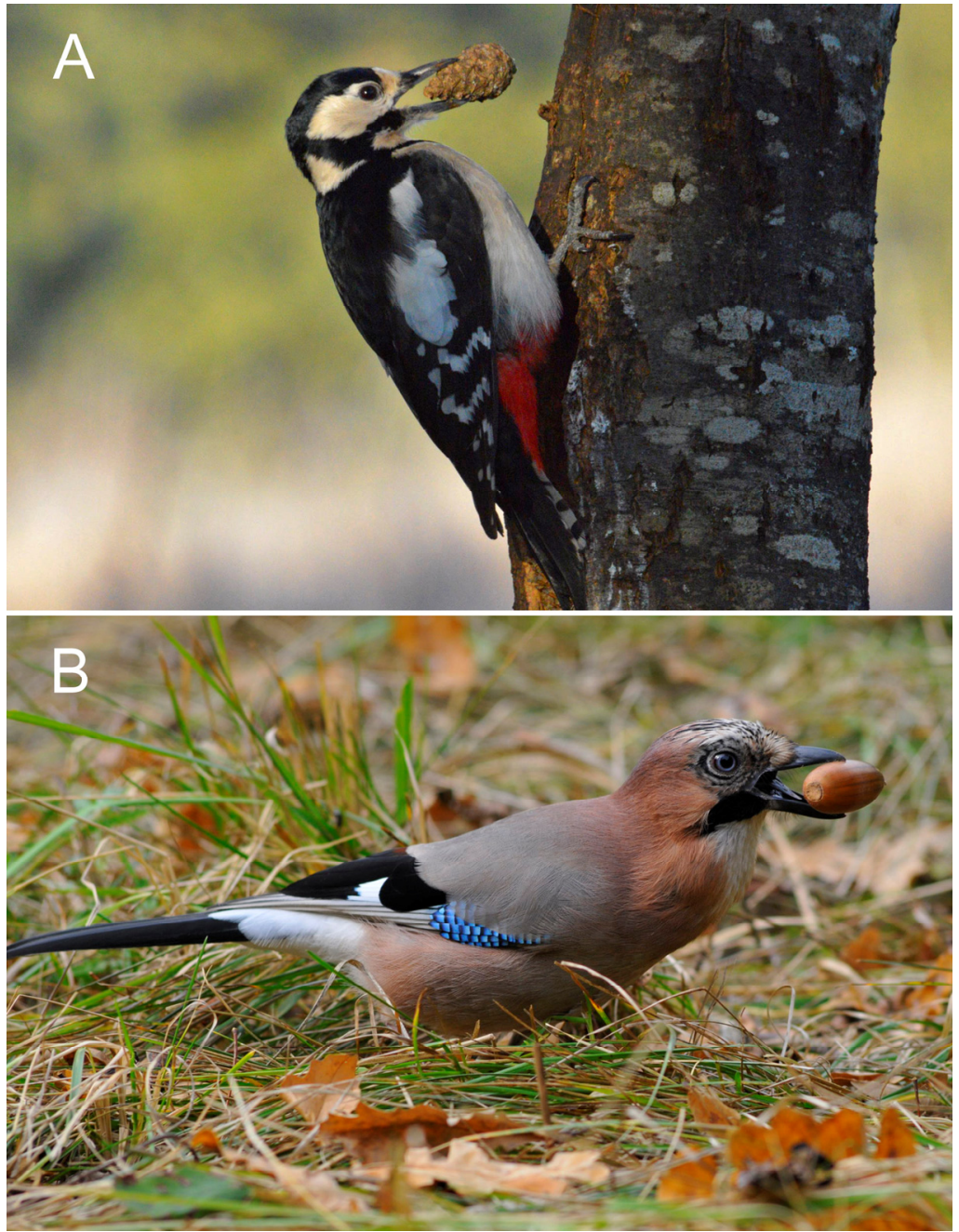

Fig. 6. Examples of synzoochoric dispersals of seeds:

A - Female of greater spotted woodpecker (Dendrocopos major) with pine cone (Pinus sylvestris L.) finds suitable forge;

$B$ - Jay (Garrulus glandarius) wants to hide an acorn in the suitable pantry. Photos by Nikolay P. Shpilenok
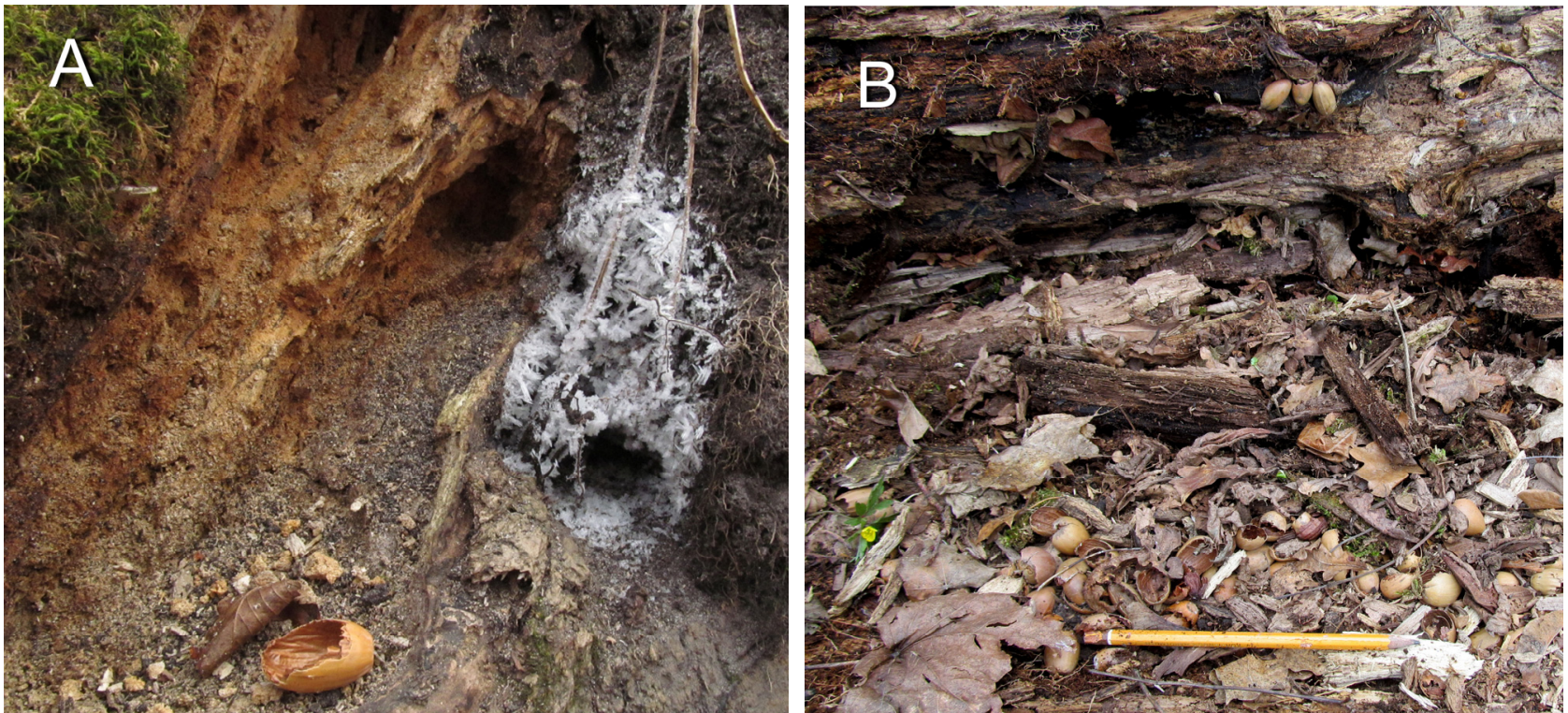

Fig. 7. Examples of synzoochoric dispersals of acorn (Quercus robur)

by yellow-necked mouse (Apademus flavicollis) in Nerussa-Sevniy zakaznik (Bryansk oblast):

A - Shell of an acorn eaten near burrow; exit of inhabited holes covered in frost (end of November 2014); $B$ - Eaten acorns in pantry under the deadwood; deadwood is raised (April 2015). Photos by Olga V. Solonina 

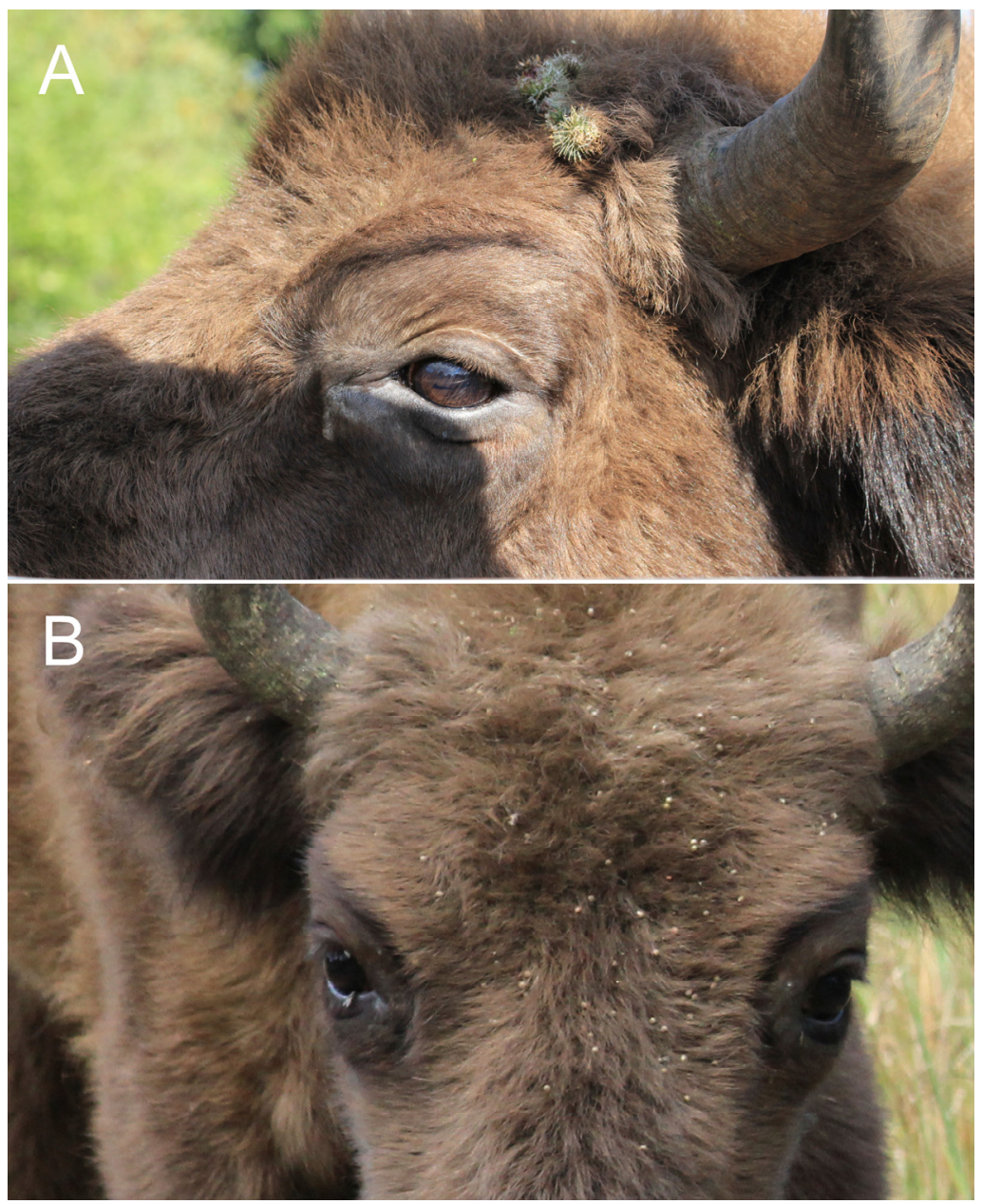

Fig. 8. Examples of epizoochoric dispersals of seeds by European wood bison (Bison bonasus) in the Bryansk Forest Nature Reserve:

A - Infructescence of great burdock (Arctium lappa L.) in bison wool;

$B$ - Seeds of Torilis japonica (Houtt.) DC and other plants in the muzzle of a bison. Photo by Elena F. Sitnikova

Other necessary conditions for zoochory and the formation of communities include 1) maintaining the viability of diaspores that have passed through the digestive tract of the animal and 2) underutilisation of collected and stocked diaspores. For instance, the viability of the seeds passing through the digestive system of Turdus pilaris is maintained at $70-100 \%$, Garrulus glandarius at 60-100\%, Ursus arctos at 30-100\% [23], and species of the family Bovidae, which include Bison bonasus, up to $95 \%$ [7]. Dendrocopos major usually consumes no more than three-quarters of seeds [20], and the rest are dispersed or scattered with pine and spruce cones (see Fig. 4,A). Observations showed that Nucifraga caryocatactes consumes less than half of stored seeds $[19,24]$ and Parus montanus only one-fifth of stored seeds [21].

The territorial behaviour of animals and zoochory. A few studies have shown that the distance of diaspore dispersals of zoochoric plant species can be estimated indirectly through the size of home ranges of animals $[10,11]$. With all the diversity, there are similarities in the territorial be- haviour of animals. Two zones are usually distinguished within the home range of one animal or its family: 1) the centre, which is actively used and protected, and 2) the periphery, which is operated and protected only intermittently or not protected at all [25]. Animals tend to actively use and protect the nest sites and daily areas. It can be assumed that plant diaspore dispersals are carried in large quantities within the central zone and in moderate quantities or sporadically within the boundaries of the peripheral zone. The area of the animal's home range has a complex configuration. In this regard, estimates of diaspore dispersal distances in this article are based on two assumptions: 1) the animal's home range is a circle and 2) the maximum distance that the animal carries the diaspores corresponds to the radius of the area of the home range.

Plant diaspore dispersals by animals in mass quantities. The distance of mass dispersal of diaspores can be estimated through the dimensions (radius) of the animal's daily home range. This is due to the fact that the bulk of the diaspores usually pass through the digestive tract during the first 
day: Turdus pilaris within 1-3 hours [23], Ursus arctos within 8-24 hours [26], Alces alces within 10-20 hours [27], Capreolus capreolus within 2024 hours [28], and species of the family Bovidae within two days [29]. An epizoochory study showed that a significant portion of adhering diaspores $(60-100 \%)$ falls off from the fur of animals in the first days [30].

Judging by the sizes of the animal's daily areas, a continuous series of mass dispersals of diaspores by animals is built (Table 1). Bison bonasus, Alces alces, Ursus arctos, and Tetrao urogallus move plant diaspores within $1 \mathrm{~km}$; Capreolus capreolus, Turdus pilaris, and Garrulus glandarius $0,5 \mathrm{~km}$; Nucifraga caryocatactes $200 \mathrm{~m}$; Sitta europaea and Parus palustris $100 \mathrm{~m}$; Parus montanus, $P$. ater, and Sciurus vulgaris $50 \mathrm{~m}$; and small rodents 20-30 m. We can expect that plant regeneration would be the most successful within the diurnal areas of animals where mass dispersal of diaspores exists.

Table 1

Sizes of animal individual areas and distances of plant diaspore disseminations

\begin{tabular}{|c|c|c|c|c|c|}
\hline \multirow{2}{*}{ Animal species } & \multicolumn{3}{|c|}{ Sizes of individual animal areas, ha } & \multicolumn{2}{|c|}{$\begin{array}{c}\text { Distances of plant diaspore } \\
\text { dispersals, } \mathrm{m}\end{array}$} \\
\hline & Daily & Seasonal & $\begin{array}{c}\text { Sources } \\
\text { of information }\end{array}$ & $\begin{array}{l}\text { in mass } \\
\text { quantity }\end{array}$ & $\begin{array}{l}\text { in moderate } \\
\text { quantity }\end{array}$ \\
\hline \multicolumn{6}{|c|}{ Animals that distribute diaspores mainly in the endozoochoric and epizoochoric ways } \\
\hline Bison bonasus L. & $70-400^{1}$ & $1,100-11,000^{1}$ & {$[32,36]$} & $470-1,100$ & $1,900-5,900$ \\
\hline Ursus arctos L. & $30-400^{1}$ & $1,500-3,500^{1}$ & [37] & $310-1,100$ & $2,200-3,300$ \\
\hline Alces alces L. & $30-300^{1}$ & $200-700^{1}$ & {$[13]$} & $310-1,000$ & $800-1,500$ \\
\hline Tetrao urogallus L. & $80-250^{2}$ & $380-1,660^{1}$ & [38] & $500-900$ & $1,100-2,300$ \\
\hline Capreolus capreolus L. & $4-100^{1}$ & $10-200^{1}$ & {$[13,28]$} & $110-560$ & $220-860$ \\
\hline Turdus pilaris $\mathrm{L}$. & $13-80^{4}$ & $150-700^{2}$ & {$[22,39]$} & $200-500$ & $700-1,500$ \\
\hline \multicolumn{6}{|c|}{ Animals that distribute diaspores mainly in the synzoochoric way } \\
\hline Garrulus glandarius L. & $13-71^{2}$ & $250-360^{1}$ & {$[22,40]$} & $200-470$ & $900-1,100$ \\
\hline Nucifraga caryocatactes L. & $5-15^{2}$ & $310^{1}$ & {$[22,41]$} & $130-220$ & 1,000 \\
\hline Dendrocopos major L. & $2-7^{3}$ & $7-13^{4}$ & {$[20,22]$} & $80-150$ & $150-200$ \\
\hline Sitta europaea L. & $1-3^{2}$ & $18-35^{1}$ & {$[22]$} & $60-100$ & $240-340$ \\
\hline Parus palustris L. & $0,8-2,5^{2}$ & $2,3-6,8^{1}$ & {$[22,42]$} & $50-90$ & $90-150$ \\
\hline Sciurus vulgaris L. & $0,6-1,0^{1}$ & $3,7-6,1^{1}$ & {$[43]$} & $45-60$ & $110-140$ \\
\hline Parus montanus Baldenstein & $0,5-1,2^{2}$ & $5,0-10,5^{1}$ & {$[22]$} & $40-60$ & $130-180$ \\
\hline Parus ater L. & $0,4-0,6^{2}$ & $2,0-3,1^{1}$ & {$[22,44]$} & $35-45$ & $80-100$ \\
\hline Apodemus flavicollis Melchior & $0,06-0,12^{1}$ & $0,15-0,29^{1}$ & {$[45,46]$} & $15-20$ & $20-30$ \\
\hline Clethrionomys glareolus Schreb. & $0,04-0,20^{1}$ & $0,10-0,48^{1}$ & {$[45,47]$} & $10-25$ & $20-40$ \\
\hline Apodemus sylvaticus L. & $0,04-0,20^{1}$ & $0,10-0,49^{1}$ & {$[48]$} & $10-25$ & $20-40$ \\
\hline
\end{tabular}

Note. Seasons: ${ }^{1}$ summer - autumn, ${ }^{2}$ autumn, ${ }^{3}$ winter, ${ }^{4}$ spring - summer. Distance of mass dissemination of diaspores was calculated as the radius of daily animal individual areas and the distance of moderate dissemination as the radius of seasonal animal areas.

Plant diaspore dispersals by animals in moderate quantities. Plant diaspores are moved in a moderate amount in the peripheral boundaries of habitats of the animal or its family (e.g., weekly or seasonal areas). Diaspores fall into the peripheral zone for different reasons. Firstly, the diaspores sometimes delay for some time in the digestive tract of the animal: in Alces alces up to two days [27], Ursus arctos and species of the family Bovidae up to four days [23, 29], and Capreolus capreolus up to six days [31]. Secondly, the animal clears its hair cover from adhering diaspores during the first few days or until the next molt. Thirdly, jays and nutcrackers soon collect a crop on their own site and continue to harvest in a neighbouring area [22]. Fourth, some animals rehide (hide in another place) part of the reserves usually [21].
The distance of moderate dispersal of diaspores can be estimated through the dimensions (radius) of the animals' seasonal home range. The range of seasonal areas is different. Accordingly, the distance of moderate dispersal of diaspores by different animal species is distinguished. A continuous series of moderate diaspores dispersal by animals is built. Bison bonasus and Ursus arctos move plant diaspores within 2-6 km; Alces alces, Tetrao urogallus, and Turdus pilaris within $1.5-2 \mathrm{~km}$; Capreolus capreolus, Garrulus glandarius, and Nucifraga caryocatactes within $1 \mathrm{~km}$; Sitta europaea within $300 \mathrm{~m}$; Dendrocopos major, Parus montanus, $P$. palustris, $P$. ater, and Sciurus vulgar$i s$ in a radius of $100-200 \mathrm{~m}$; and small rodents within 30-40 m (see Table 1). We can expect that plant regeneration will be satisfactory within sea- 
sonal areas of animals where moderate dispersal of diaspores exists.

Plant diaspore dispersals by animals in single quantities. Long-distance movement of animals contributes to dispersal of individual plant diaspores over long distances. This distance can be estimated by the length of nomading or migrations of animals. For example, the extent of migration of Bison bonasus and Alces alces is $100-300 \mathrm{~km}$ and of Capreolus capreolus 10-70 km [13, 28, 32]. Adapting to changing environmental conditions, the animals change their feeding behaviour; for example, Garrulus glandarius and Nucifraga caryocatactes in a good oak fruiting year make reserves in a small area, and during a poor harvest of acorns they fly over long distances of $6 \mathrm{~km}$ or more $[22,33]$.

Long-distance dispersal of diaspores is necessary mainly for the expansion of the population area [34]. These movements are more common for species in which diaspores are attached to the animals (see Fig. 8), as well as for species with small seeds that can delay in the digestive tract for many days. Researchers who study dissemination believe that mass drift of diaspores is essential for the success of long-distance migration and for formation of communities at this distance, and cases of a single drift of seeds for tens of kilometres from the mother plant do not have a special significance for the formation of plant communities [7, 35]. Based on the analysis of a large volume of scientific publications, Udra [2] attributes this to the fact that single-growing individuals with autogamy have extremely low seed productivity that does not allow them to form a complete population.

The role of large animals in zoochory. Animals with large and small areas of home range play a different role in successional dynamics. Animals with large areas organise mainly inter-coenotic flows of diaspores. These flows are necessary to change the communities. Examples of such changes are 1) the formation of a forest community in a meadow and 2) the conversion of dark broadleaved nemoral communities to a light park forest with a steppefied herb cover. Two factors suggest that large animals move seeds from one community to another. Firstly, the feed of these animals includes plant species from different types of communities; species from forest, meadow, and marsh ecosystems are found in significant number in the food composition of European bison, elk, roe deer, brown bear, and wood grouse (Table 2). Secondly, the study of ungulate nutrition has showed that animals transfer a significant portion of seeds outside of the community, with bison at more than $80 \%$ [49] and red deer at about $90 \%$ [50].

Table 2

Number of plant species in animal feeds and their ecological-coenotic composition

\begin{tabular}{|c|c|c|c|c|c|}
\hline \multirow{2}{*}{ Animal species } & \multirow{2}{*}{$\begin{array}{c}\text { Number } \\
\text { of plant species } \\
\text { in animal feed }\end{array}$} & \multirow{2}{*}{$\begin{array}{l}\text { Main sources } \\
\text { of information }\end{array}$} & \multicolumn{3}{|c|}{$\begin{array}{c}\text { Percent of plant species } \\
\text { by ecological-coenotic groups }\end{array}$} \\
\hline & & & Forest & Water-marsh & $\begin{array}{l}\text { Meadow, } \\
\text { forest edge }\end{array}$ \\
\hline Bison bonasus L. & 385 & {$[51-53]$} & 24 & 16 & 60 \\
\hline Capreolus capreolus L. & 256 & {$[28,31]$} & 27 & 27 & 46 \\
\hline Alces alces $\mathrm{L}$. & 163 & {$[54,55]$} & 29 & 35 & 36 \\
\hline Tetrao urogallus L. & 156 & {$[7,18,22,38,56]$} & 35 & 26 & 39 \\
\hline Ursus arctos L. & 144 & {$[23,26]$} & 37 & 22 & 41 \\
\hline Garrulus glandarius L. & 44 & {$[7,18,22,23,57]$} & 73 & 9 & 18 \\
\hline Nucifraga caryocatactes L. & 41 & {$[7,18,22,57,58]$} & 68 & 20 & 12 \\
\hline Turdus pilaris $\mathrm{L}$. & 39 & {$[7,22,23]$} & 64 & 15 & 21 \\
\hline Dendrocopos major L. & 32 & {$[7,22,57]$} & 88 & 6 & 6 \\
\hline Sciurus vulgaris L. & 32 & {$[7,16-18]$} & 78 & 9 & 13 \\
\hline Sitta europaea L. & 17 & {$[18,22,57]$} & 82 & - & 18 \\
\hline Parus palustris L. & 42 & {$[18,22,57]$} & 62 & 12 & 26 \\
\hline Parus montanus Baldenstein & 31 & {$[18,22,57]$} & 58 & 6 & 36 \\
\hline Parus ater $\mathrm{L}$. & 21 & {$[18,22,57]$} & 76 & 5 & 19 \\
\hline $\begin{array}{l}\text { Apodemus flavicollis } \\
\text { Melchior }\end{array}$ & 38 & {$[7,17,23]$} & 81 & 3 & 16 \\
\hline $\begin{array}{l}\text { Clethrionomys glareolus } \\
\text { Schreb. }\end{array}$ & 32 & {$[7,17,23]$} & 72 & 6 & 22 \\
\hline Apodemus sylvaticus L. & 28 & {$[7,17]$} & 79 & - & 21 \\
\hline
\end{tabular}

The role of small animals in zoochory. Animals with a relatively small home range create mainly intra-coenotic flows of diaspores. These flows are necessary to maintain the population within a community, for maintenance of the species diversity of a community, as well as for ensur- 
ing propagula for microsuccession within community. Examples of intra-coenotic successions are 1) the regeneration of treefall gaps in a forest community and 2) the forming of plant microgroups in forests. Feed composition demonstrates that animals with a small home range move diaspores preferably within a community. Thus, plant species of forest communities dominated in the nutrition of Garrulus glandarius, Nucifraga caryocatactes, Sitta europaea, Parus sp., Sciurus vulgaris, Apodemus sp., and Clethrionomys sp. (Table 2). Additionally, it is known that Nucifraga caryocatactes hides no more than half of seeds outside Pinus sibirica forests [58, 59]. Observations in the Bryansk Forest nature reserve showed that Garrulus glandarius moves only one-third of seeds outside the forest community, Sitta europaea only onefifth, and Parus ater and P. palustris just a small percentage of seeds [8].

Features of zoochory in coniferousbroadleaved forests. Three groups of plant spe- cies were distinguished on adaptation to diaspore dispersal by animals (Table 3 ). The first group includes plants with juicy fruits (e.g., Malus sylvestris, Sorbus aucuparia, Vaccinium myrtillus). A wide range of animals disperse diaspores of these plants at a distance of $20 \mathrm{~m}$ (small rodents) to $1,000 \mathrm{~m}$ (large birds and mammals) in the endozoochoric and synzoochoric ways (see Fig. 1-3). The second group includes plants with large and dry seeds (e.g., Corylus avellana, Fraxinus excelsior, Quercus robur). The seeds of these plants are dispersed in the synzoochoric way by animals (small rodents, Sciurus vulgaris, Parus sp., Sitta europaea, Garrulus glandarius, Nucifraga caryocatactes) that stock seeds at a distance of $20 \mathrm{~m}$ to 500 $\mathrm{m}$ (see Fig. 4-7). The third group includes plants with small and dry diaspores (e.g., Aegopodium podagraria, Melica nutans, Stellaria holostea и др.). Diaspores of these species are dispersed by ungulates in the endozoochoric way in large quantities at a distance of up to $1,000 \mathrm{~m}$ (see Table 3 ).

Table 3

Examples of diaspore mass dispersal distances of coniferous-broadleaved forest plants by vertebrate animals $[13,16-18,22,23,31,33,51,52,55,56]$

\begin{tabular}{|c|c|c|c|c|c|c|c|c|c|c|c|c|c|c|c|c|c|}
\hline \multirow[b]{3}{*}{ Plant species } & \multicolumn{17}{|c|}{ Diaspore mass dispersal distance by animals ${ }^{1}, \mathrm{~m}$} \\
\hline & ్ㅗ & $\approx$ & $\stackrel{n}{\sim}$ & $\mathscr{q}$ & 8 & 8 & § & $\stackrel{8}{ }$ & $\stackrel{n}{=}$ & ત્ & 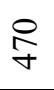 & $\underset{n}{8}$ & $\stackrel{8}{i}$ & ஓু & $\stackrel{8}{8}$ & $\stackrel{8}{\varrho}$ & $\stackrel{8}{\varrho}$ \\
\hline & 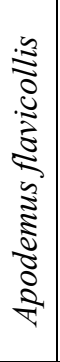 & 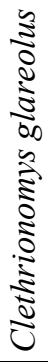 & 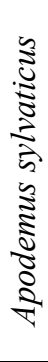 & 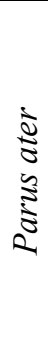 & 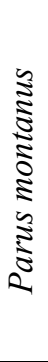 & 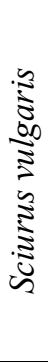 & 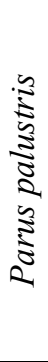 & 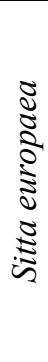 & 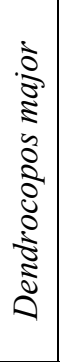 & 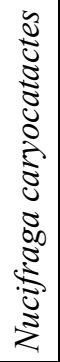 & 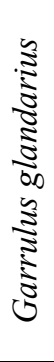 & 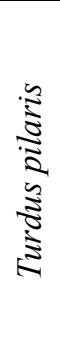 & 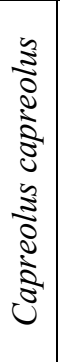 & 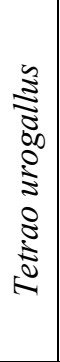 & 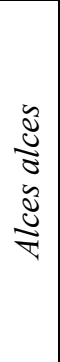 & $\begin{array}{l}2 \\
0 \\
0 \\
\vdots \\
\vdots \\
0 \\
0 \\
\vdots \\
5\end{array}$ & 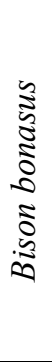 \\
\hline 1 & 2 & 3 & 4 & 5 & 6 & 7 & 8 & 9 & 10 & 11 & 12 & 13 & 14 & 15 & 16 & 17 & 18 \\
\hline \multicolumn{18}{|c|}{ Plants with juicy fruits disseminated in the endozoochoric and synzoochoric ways } \\
\hline Sorbus aucuparia $\mathrm{L}$. & + & + & + & + & + & + & + & + & + & + & + & + & + & + & + & + & + \\
\hline Rubus spp. & + & + & + & & + & + & + & & + & + & + & + & + & + & + & + & + \\
\hline Malus sylvestris Mill. & + & + & + & & & + & + & + & + & + & + & + & + & & + & + & + \\
\hline Vaccinium myrtillus L. & + & + & & & + & + & + & & + & + & + & + & + & + & + & + & + \\
\hline Lonicera xylosteum L. & + & + & + & & + & & + & & & + & + & + & + & + & + & + & + \\
\hline Sambucus racemosa L. & + & + & + & & & & + & + & + & + & + & + & + & + & + & & + \\
\hline Frangula alnus Mill. & & + & & & & & + & & + & + & + & + & + & + & + & + & + \\
\hline Euonymus spp. & + & + & + & + & & & + & & & + & + & + & + & & + & & + \\
\hline Pyrus communis L. & + & & & & & + & + & + & + & + & & + & + & & + & + & + \\
\hline Convallaria majalis L. & + & + & & & & & & & + & & + & + & + & + & + & + & + \\
\hline Swida sanguinea (L.) Opiz & + & & + & & & & & & & & + & + & + & & + & & + \\
\hline \multicolumn{18}{|c|}{ Plants with large and dry diaspores disseminated in the synzoochoric way } \\
\hline Picea abies (L.) Karst. & + & + & + & + & + & + & + & + & + & + & + & & & & & & \\
\hline Acer spp. & + & + & + & + & + & + & + & + & + & + & + & & & & & & \\
\hline Pinus sylvestris L. & + & & & + & + & + & + & + & + & + & + & & & & & & \\
\hline Tilia cordata Mill. & + & + & + & & + & + & & + & + & + & + & & & & & & \\
\hline Quercus robur L. & + & + & + & & & + & & + & + & + & + & & & & & & \\
\hline
\end{tabular}


End of table 3

\begin{tabular}{|l|c|c|c|c|c|c|c|c|c|c|c|c|c|c|c|c|c|}
\hline \multicolumn{1}{|c|}{1} & 2 & 3 & 4 & 5 & 6 & 7 & 8 & 9 & 10 & 11 & 12 & 13 & 14 & 15 & 16 & 17 & 18 \\
\hline Corylus avellana L. & + & + & + & & & + & & + & + & + & + & & & & & & \\
\hline Fraxinus excelsior L. & + & + & + & & + & & + & + & + & + & & & & & & & \\
\hline Carpinus betulus L. & + & & & + & & & + & + & + & + & + & & & & & & \\
\hline & + & + & + & & & & & + & + & & & & & & & & \\
\hline \\
\hline Plmus spp.
\end{tabular}

Note. ${ }^{1}$ Seed dispersal distance is equal to radius of daily animal individual area (see Table 1 ). ${ }^{2}$ The species also adapted to epizoochory. ${ }^{3}$ Some species adapted to epizoochory. ${ }^{4}$ Species also adapted to myrmecochory. «+» - Plants that are marked as part of animal feed.

However, current numbers of most large animals are negligible or zero in coniferousbroadleaved forests due to human activity. Consequently, participation of plant species with small and dry diaspores has become unlikely in succession outside native forests. The seeds of these species are dispersed only by animals with small home ranges (ants, small rodents, tits) at a distance not exceeding $60 \mathrm{~m}$. Thus, in the modern vegetation cover, inter-coenotic flows of diaspores are practically absent for plants with small and dry seeds, which are necessary for expansion of the population area, avoidance of unfavourable changing conditions in the plant community, and participation in successions. The extremely low number of populations and incomplete species composition of large animals that disperse plant diaspores are reasons for the formation of subclimax forests with poor plant species composition [4, 5, 53, 60-64].

\section{Conclusion}

Mass and moderate dispersals of plant diaspores by animals are important for the formation of plant communities, but long-distance dispersals of single diaspores are significant for expansion of the habitat area of plant populations. Mass and moderate diaspore dispersals of zoochoric plant species are carried within the individual home ranges of animals, and a single dispersal in the course of long-distance movements of animals during migrations. The distance of mass and moderate dispersals of zoochoric plant diaspores can be assessed by the size of individual home ranges of animals, and a single dispersal by the length of migrations.

The role of zoochory in population and community life depends on the distance of plant diaspora dispersals by animals. The dispersal distance may be smaller or larger than the size of communities. If diaspores move within the community, zoochory helps maintain populations within the community and conserve the species diversity of the plant community. If diaspores are transferred outside of community limits, zoochory introduces populations in other communities and creates conditions for changes of coenoses.

The diversity and high number of animals with their different sizes of home ranges introduce a maximum number of seeds, fruits, and vegetative propagula into diaspore streams. The reduction in species diversity and abundance of animals (dissemination agents) due to human activity limits the participation of zoochoric plant species in successions, significantly weakens inter-coenotic flows of diaspores, and leads to the formation of subclimax communities with diminished species diversity.

\section{Acknowledgements}

We are grateful to Alina S. Teslyuk for the expressive painting of jay as well as to Elena F. Sitnikova, Olga V. Solonina, Alexey V. Gornov and Nikolay P. Shpilenok for their nice photos. 


\section{References}

1. Заугольнова, Л. Б. Ценопопуляции растений (очерки популяционной биологии) / Л. Б. Заугольнова, Л. А. Жукова, О. В. Смирнова, А. С. Комаров. - М. : Наука, 1988. -184 с.

2. Удра, И. Ф. Расселение растений и вопросы палео- и биогеографии / И. Ф. Удра. - Киев : Наук. думка, 1988. -197 c.

3. Смирнова, О. В. Сукцессия и климакс как экосистемный процесс / О. В. Смирнова, Н. А. Торопова // Успехи современной биологии. - 2008. - Т. 128. - № 2. - С. 129-144.

4. Коротков, В. Н. Демутационные процессы в островных лесных массивах (на примере ГИЗЛ «Горки Ленинские» и Каневского заповедника) : автореф. дис. ... канд. биол. наук / В. Н. Коротков. - М. : МГПИ им. В. И. Ленина, 1992. - 16 с.

5. Восточноевропейские леса: история в голоцене и современность. - М. : Наука, 2004. - Кн. 2. - 575 с.

6. Евстигнеев, О. И. Формирование лесной растительности на лугах (на примере Неруссо-Деснянского полесья) / О. И. Евстигнеев, П. В. Воеводин // Бюллетень Московского общества испытателей природы. Отдел биологический. - 2013. - Т. 118. - Вып. 4. - С. 64-70.

7. Левина, Р. Е. Способы распространения плодов и семян / Р. Е. Левина. - М. : Изд-во МГУ, 1957. - 358 с.

8. Евстигнеев, О. И. Зоохория и дальность разноса семян в хвойно-широколиственных лесах Восточной Европы / О. И. Евстигнеев, П. В. Воеводин, В. Н. Коротков, И. А. Мурашев // Успехи современной биологии. 2013. - Т. 133. - № 4. - С. 392-400.

9. Евстигнеев, О. И. Анемохория и дальность рассеивания семян деревьев Восточноевропейских лесов / О. И. Евстигнеев, И. А. Мурашев, В. Н. Коротков // Лесоведение. - 2017. - № 1. - С. 45-52.

10. Rosalino, L. M. Spatial structure and land-cover use in a low-density Mediterranean population of Eurasian badgers / L. M. Rosalino, D. W. Macdonald, M. Santos-Reis // Canadian Journal of Zoology. - 2004. - V. 82 (9). P. $1493-1502$.

11. Holbrook, K. M. Home Range and Movement Patterns of Toucans: Implications for Seed Dispersal / K. M. Holbrook // Biotropica. - 2011. - V. 43 (3). - P. 357-364.

12. Холодова, М. В. Потребление и усвоение питательных веществ и энергии зубрами (Bison bonasus)/ М. В. Холодова, И. П. Белоусова // Зоологический журнал. - 1989. - Т. 68. - Вып. 12. - С. 107-117.

13. Данилкин, А. А. Оленьи (Cervidae) / А. А. Данилкин. - М. : ГЕОС, 1999. - 552 с.

14. Котт, С. А. Сорные растения и меры борьбы с ними / С. А. Котт. - М. : Сельхозгиз, 1955. - 384 с.

15. Башта, А. Т. Роль орнітохорії в процесі лісовідтворення // Пріоритети орнітологічних досліджень / А. Т. Башта. - Львів : Кам' янець-Подільский держ. ун-т, 2003. - С. 95-97.

16. Кирис, И. Д. Белка / И. Д. Кирис. - Киров : Волго-Вят. кн. изд-во, 1973. - 448 с.

17. Свириденко, П. А. Запасание корма животными / П. А. Свириденко. - Киев : Изд-во АН УССР, 1957. $156 \mathrm{c}$.

18. Формозов, А. Н. Звери, птицы и их взаимоотношения со средой обитания / А. Н. Формозов. - M. : URSS, 2010. $-309 \mathrm{c}$.

19. Воробьев, В. Н. Кедровка и ее взаимосвязи с кедром сибирским / В. Н. Воробьев. - Новосибирск : Наука, 1982. $-113 \mathrm{c}$.

20. Dobrowolski, K. A. Foraging and territorial behaviours in great spotted woodpecker (Dendrocopus major) / K. A. Dobrowolski, R. Halba, D. Markiewicz, K. Markiewicz, R. Szczepanowski // Ecologie. - 1994. - V. 25 (2). P. 119-126.

21. Правосудов, В. В. Поиск и запасание корма сероголовой гаичкой и пухляком / В. В. Правосудов // Зоологический журнал. - 1985. - Т. 64. - Вып. 7. - С. 1036-1043.

22. Cramp, S. The complete birds of the Western Palearctic on CD-ROM / S. Cramp. - UK, Oxford. - 1998.

23. Образцов, Б. В. Материалы опытов и наблюдений по распространению дикими животными семян деревьев и кустарников в открытые биотопы лесостепи / Б. В. Образцов // Сообщения лаборатории лесоведения. М. : Изд-во АН СССР, 1961. - Вып. 3. - С. 69-88.

24. Kajimoto, T. Factors affecting seedling recruitment and survivorship of the Japanese subalpine stone pine, Pinus pumila, after seed dispersal by nutcrackers / T. Kajimoto // Ecological Research. - 2002. - V. 17. - P. 481-491.

25. Панов, Е. Н. Поведение животных и этологичекая структура популяций / Е. Н. Панов - M. : URSS, 2009. $423 \mathrm{c}$.

26. Пажетнов, В. С. Бурый медведь / В. С. Пажетнов. - М. : Агропромиздат, 1990. - 215 с.

27. Вебер, А. Э. Физиология питания и обмен веществ лося / А. Э. Вебер, А. Ф. Симаков, Н. И. Увьюрова и др. Сыктывкар : Коми науч. центр УрО РАН, 1992. - 128 c.

28. Schmidt, M. Dispersal of vascular plants by game in northern Germany. Part I: Roe deer (Capreolus capreolus) and wild boar (Sus scrofa) / M. Schmidt, K. Sommer, W.-U. Kriebitzsch, H. Jr. Ellenberg, G. Oheimb // European Journal Forest Research. - 2004. - V. 123. - P. 167-176.

29. Willms, W. D. Feasibility of using cattle to disperse cicer milkvetch (Astragalus cicer L.) seeds in pastures / W. D. Willms, S. N. Acharya, L. M. Rode // Canadian Journal of Animal Science. - 1995 - V. 75 (1). - P. 173-175.

30. Couvreur, M. Experimental assessment of plant seed retention times in fur of cattle and horse / M. Couvreur, K. Verheyen, M. Hermy // Flora. - 2005. - V. 200. - P. 112-131. 
31. Тимофеева, Е. К. Косуля / Е. К. Тимофеева. - Л. : Изд-во ЛГУ, 1985. - 224 с.

32. Казьмин, В. Д. Зимнее питание, кормовые ресурсы и трофическое воздействие зубра на лесные фитоценозы Центрального Кавказа / В. Д. Казьмин, К. А. Смирнов // Бюллетень Московского общества испытателей природы. Отдел биологический. - 1992. - Т. 97. - Вып. 2. - С. 26-35.

33. Нечаев, В. А. Биоценотические связи птиц с кедровым стлаником (Pinus pumila) / В. А. Нечаев // Вестник СВНЦ ДВО РАН. - 2013. - № 1. - С. 49-59.

34. Ndiade-Bourobou, D. Long-distance seed and pollen dispersal inferred from spatial genetic structure in the very low-density rainforest tree, Baillonella toxisperma Pierre, in Central Africa / D. Ndiade-Bourobou, O. J. Hardy, B. Favreau et al. // Molecular Ecology. - 2010. - V. 19. - P. 4949-4962.

35. Ермилов, Г. Б. О распространении и концентрации семян / Г. Б. Ермилов // Доклады АН СССР. - 1952. T. 84 (3). - C. 599-601.

36. Krasińska, M. Factors affecting the variability in home range size and distribution in European bison in the Polis and Byelorussia parts of the Bialowieźa Forest / M. Krasińska, Z. A. Krasiński, A. N. Bunevich // Acta Theriologica. - 2000. - V. 45 (3). - P. 321-334.

37. Медведи. - М. : Наука, 1993. - 519 с.

38. Романов, А. Н. Глухарь / А. Н. Романов. - М. : Агропромиздат, 1988. - 192 с.

39. Симкин, Г. Н. Певчие птицы / Г. Н. Симкин. - М. : Лесн. пром-сть, 1990. - 399 с.

40. Rolando, A. Factors affecting movements and home ranges in the jay (Garrulus glandarius) / A. Rolando // Journal of Zoology. - 1998. - V. 246. - P. 249-257.

41. Rolando, A. Home range and habitat selection by the Nutcracker (Nucifraga catyocatactes) during autumn in the Alps / A. Rolando // Ibis. - 1996. - V. 138. - P. 384-390.

42. Марковец, М. Ю. Популяционная экология гаички (Parus palustris) : автореф. дис. ... канд. биол. наук / М. Ю. Марковец. - СПб: Зоол. ин-т РАН, - 2001. - 22 с.

43. Богодяж, О. М. Биология белки (Sciurus vulgaris L.) на европейском северо-западе : автореф. дис. ... канд. биол. наук / О. М. Богодяж. - Л. : ЛГУ, 1988. - 16 с.

44. Иноземцев, А. А. Роль насекомоядных птиц в лесных биогеоценозах / А. А. Иноземцев. - Л. : Изд-во ЛГУ, 1978. - $264 \mathrm{c}$.

45. Меркова, М. А. Некоторые данные по экологии рыжей полевки и желтогорлой мыши юга Московской области и Теллермановской рощи / М. А. Меркова // Бюллетень Московского общества испытателей природы. Отдел биологический. - 1955. - Т. 60. - Вып. 1. - С. 21-31.

46. Голикова, В. Л. Особенности использования территории лесными мышевидными грызунами в Поволжье и других частях их ареала / В. Л. Голикова // Вопросы биогеографии Среднего и Нижнего Поволжья. - Саратов : Изд-во Сарат. ун-та, 1968. - С. 267-292.

47. Кутенков, А. П. Пространственная структура популяций рыжей полёвки в условиях северной половины ареала / А. П. Кутенков // Мелкие млекопитающие заповедных территорий. - М. : Гл. упр. охот. хоз-ва, 1984. - C. 45-58.

48. Никитина, Н. А. Использование территории мышами и полевками по данным мечения / Н. А. Никитина, М. А. Меркова // Бюллетень Московского общества испытателей природы. Отдел биологический. - 1963. Т. 68. - Вып. 5. - С. 15-21.

49. Jaroszewicz, B. The European bison as seed dispersers: the effect on the species composition of a disturbed pine forest community / B. Jaroszewicz, E. Piroz nikow, R. Sagehorn // Botany. - 2008. - V. 86. - P. 475-484.

50. Malo, J. E. The dispersal of a dry-fruited shrub by red deer in Mediterranean ecosystem / J. E. Malo, F. Suárez // Ecography. - 1998. - V. 21. - P. 204-211.

51. Корочкина, Л. Н. Видовой состав лесной травянистой растительности в питании зубров Беловежской Пущи / Л. Н. Корочкина // Беловежская Пуща. - Минск : Ураджай, 1969. - С. 204-221.

52. Корочкина, Л. Н. Травянистая растительность в питании зубров Беловежской Пущи / Л. Н. Корочкина // Беловежская Пуща. - Минск : Ураджай, 1972. - С. 204-221.

53. Евстигнеев, О. И. Механизмы поддержания биологического разнообразия лесных биогеоценозов : дис. ... д-ра биол. наук. - Нижний Новгород : ННГУ им. Н. И. Лобачевского, 2010. - 513 с.

54. Калецкий, А. А. Растительные корма лося в летне-осенний период // Биология и промысел лося / А. А. Калецкий. - М. : Россельхозиздат, 1965. - С. 113-135.

55. Тимофеева, Е. К. Лось / Е. К. Тимофеева. - Л. : Изд-во ЛГУ, 1974. - 168 с.

56. Saniga, M. Diet of capercaillie (Tetrao urogallus) in a Central-European mixed spruce-beech-fir and mountain spruce forest / M. Saniga // Folia Zoologica. - 1998. - V. 47 (2). - P. 115-124.

57. Нечаев, В. А. Птицы - потребители и распространители плодов и семян древесных растений в Приморском крае / В. А. Нечаев // Бюллетень Московского общества испытателей природы. Отдел биологический. 2001. - Т. 106. - Вып. 2. - С. 14-21.

58. Бибиков, Д. И. К экологии кедровки / Д. И. Бибиков // Тр. Печорско-Ылычского государственного заповедника. - М. : Глав. упр. по заповедникам при СНК РСФСР, 1948. - Вып. 4. - Ч. 2. - С. 89-112.

59. Москвитин, С. С. Роль позвоночных животных в продуктивности припоселковых кедровников и плодовоягодных садов Томской области / С. С. Москвитин, А. А. Ананин, Н. С. Москвитина, О. Г. Нехорошев // Пути рационального использования почвенных, растительных и животных ресурсов Сибири. - Томск : Изд-во ТГУ, 1986. - С. 189-191. 
60. Евстигнеев, О. И. Сукцессии сосновых лесов зандровой местности Неруссо-Деснянского полесья / О. И. Евстигнеев, В. Н. Коротков // Бюллетень Брянского отделения Российского ботанического общества. 2013. - № 1. - С. 31-41.

61. Евстигнеев, О. И. Популяционная организация и антропогенные преобразования пойменной дубравы реки Большая Кокшага / О. И. Евстигнеев, М. В. Почитаева, С. Е. Желонкин // Бюллетень Московского общества испытателей природы. Отдел биологический. - 1993. - Т. 98. - Вып. 5. - С. 80-87.

62. Популяционная диагностика и прогнозы развития заповедных лесных массивов (на примере Каневского заповедника) / О. В. Смирнова, Р. Р. Возняк, О. И. Евстигнеев, В. Н. Коротков, Н. Я. Носач, Р. В. Попадюк, В. К. Самойленко, Н. А. Торопова // Ботанический журнал. - 1991. - Т. 76. - № 6. - С. 68-79.

63. Evstigneev, O. I. Pine Forest Succession on Sandy Ridges within Outwash Plain (Sandur) in Nerussa-Desna Polesie / O. I. Evstigneev, V. N. Korotkov // Russian Journal of Ecosystem Ecology. - 2016. - Vol. 1 (3). P. 1-18.

64. Евстигнеев, О. И. Популяционная организация грабовых лесов Каневского заповедника / О. И. Евстигнеев, В. Н. Коротков, Л. В. Бакалына // Бюллетень Московского общества испытателей природы. Отдел биологический. - 1992. - Т. 97. - Вып. 2. - С. 81-89.

\section{References}

1. Zaugol'nova L. B., Zhukova L. A., Smirnova O. V., Komarov A. S. Tsenopopulyatsii rasteniy (ocherki populyatsionnoy biologii) [Cenopopulation of plants (reviews on populational biology)]. Moscow: Nauka, 1988, $184 \mathrm{p}$.

2. Udra I. F. Rasselenie rasteniy $i$ voprosy paleo- $i$ biogeografii [Dissemination of plants and issues on paleo- and biogeography]. Kiev: Nauk. dumka, 1988, 197 p.

3. Smirnova O. V., Toropova N. A. Uspekhi sovremennoy biologii [Achievements of modern biology]. 2008, vol. 128 , no. 2 , pp. 129-144.

4. Korotkov V. N. Demutatsionnye protsessy v ostrovnykh lesnykh massivakh (na primere GIZL «Gorki Leninskie» i Kanevskogo zapovednika): avtoref. dis. kand. biol. nauk [Demutational processes in insular forest areas]. Moscow: MGPI im. V. I. Lenina, 1992, 16 p.

5. Vostochnoevropeyskie lesa: istoriya v golotsene $i$ sovremennost' [East European forests: history in Holocene and modern times]. Moscow: Nauka, 2004, bk. 2, 575 p.

6. Evstigneev O. I., Voevodin P. V. Byulleten' Moskovskogo obshchestva ispytateley prirody. Otdel biologicheskiy [Bulletin of Moscow Society of Naturalists. Biological series]. 2013, vol. 118, iss. 4, pp. 64-70.

7. Levina R. E. Sposoby rasprostraneniya plodov $i$ semyan [Ways of disseminating fruits and seeds]. Moscow: Izd-vo MGU, 1957, 358 p.

8. Evstigneev O. I., Voevodin P. V., Korotkov V. N., Murashev I. A. Uspekhi sovremennoy biologii [Achievements of modern biology]. 2013, vol. 133, no. 4, pp. 392-400.

9. Evstigneev O. I., Murashev I. A., Korotkov V. N. Lesovedenie [Forest studies]. 2017, no. 1, pp. 45-52.

10. Rosalino L. M., Macdonald D. W., Santos-Reis M. Canadian Journal of Zoology. 2004, vol. 82 (9), pp. 1493-1502.

11. Holbrook K. M. Biotropica. 2011, vol. 43 (3), pp. 357-364.

12. Kholodova M. V., Belousova I. P. Zoologicheskiy zhurnal [Zoological journal]. 1989, vol. 68, iss. 12, pp. $107-117$.

13. Danilkin A. A. Olen'i (Cervidae) [Deers (Cervidae)]. Moscow: GEOS, 1999, 552 p.

14. Kott S. A. Sornye rasteniya i mery bor'by s nimi [Weed plants and measures against them]. Moscow: Sel'khozgiz, $1955,384 \mathrm{p}$.

15. Bashta A. T. Prioriteti ornitologichnikh doslidzhen' [Priorities of ornithological achievements]. L'viv: Kam' yanets'Podil'skiy derzh. un-t, 2003, pp. 95-97.

16. Kiris I. D. Belka [Squirrel]. Kirov: Volgo-Vyat. kn. izd-vo, 1973, 448 p.

17. Sviridenko P. A. Zapasanie korma zhivotnymi [Food caching by animals]. Kiev: Izd-vo AN USSR, 1957,156 p.

18. Formozov A. N. Zveri, ptitsy i ikh vzaimootnosheniya so sredoy obitaniya [Animals, birds and their relationships with the habitat]. Moscow: URSS, 2010, 309 p.

19. Vorob'ev V. N. Kedrovka i ee vzaimosvyazi s kedrom sibirskim [Nutcracker and its interconnection with Siberian cedar]. Novosibirsk: Nauka, 1982, 113 p.

20. Dobrowolski K. A., Halba R., Markiewicz D., Markiewicz K., Szczepanowski R. Ecologie. 1994, vol. 25 (2), pp. 119-126.

21. Pravosudov V. V. Zoologicheskiy zhurnal [Zoological journal]. 1985, vol. 64, iss. 7, pp. 1036-1043.

22. Cramp S. The complete birds of the Western Palearctic on CD-ROM. UK, Oxford, 1998.

23. Obraztsov B. V. Soobshcheniya laboratorii lesovedeniya [Reports of forest studies laboratory]. Moscow: Izd-vo AN SSSR, 1961, iss. 3, pp. 69-88.

24. Kajimoto T. Ecological Research. 2002, vol. 17, pp. 481-491.

25. Panov E. N. Povedenie zhivotnykh i etologichekaya struktura populyatsiy [Animal behavior and ecological structure of population]. Moscow: URSS, 2009, $423 \mathrm{p}$.

26. Pazhetnov V. S. Buryy medved' [Brown bear]. Moscow: Agropromizdat, 1990, 215 p. 
27. Veber A. E., Simakov A. F., Uv'yurova N. I. et al. Fiziologiya pitaniya i obmen veshchestv losya [Nutrition physiology and metabolism of a moose]. Syktyvkar: Komi nauch. tsentr UrO RAN, 1992, 128 p.

28. Schmidt M., Sommer K., Kriebitzsch W.-U., Ellenberg H. Jr., Oheimb G. European Journal Forest Research. 2004, vol. 123, pp. 167-176.

29. Willms W. D., Acharya S. N., Rode L. M. Canadian Journal of Animal Science. 1995, vol. 75 (1), pp. $173-175$.

30. Couvreur M., Verheyen K., Hermy M. Flora. 2005, vol. 200, pp. 112-131.

31. Timofeeva E. K. Kosulya [Roedeer]. Leningrad: Izd-vo LGU, 1985, 224 p.

32. Kaz'min V. D., Smirnov K. A. Byulleten' Moskovskogo obshchestva ispytateley prirody. Otdel biologicheskiy [Bulletin of Moscow Society of Naturalists]. 1992, vol. 97, iss. 2, pp. 26-35.

33. Nechaev V. A. Vestnik SVNTs DVO RAN [Proceedings of SVNT DVO RAS]. 2013, no. 1, pp. 49-59.

34. Ndiade-Bourobou D., Hardy O. J., Favreau B. et al. Molecular Ecology. 2010, vol. 19, pp. 4949-4962.

35. Ermilov G. B. Doklady AN SSSR [Proceedings of AS USSR]. 1952, vol. 84 (3), pp. 599-601.

36. Krasińska M., Krasiński Z. A., Bunevich A. N. Acta Theriologica. 2000, vol. 45 (3), pp. 321-334.

37. Medvedi [Bears]. Moscow: Nauka, 1993, 519 p.

38. Romanov A. N. Glukhar' [Wood grouse]. Moscow: Agropromizdat, 1988, 192 p.

39. Simkin G. N. Pevchie ptitsy [Song birds]. Moscow: Lesn. prom-st', 1990, 399 p.

40. Rolando A. Journal of Zoology. 1998, vol. 246, pp. 249-257.

41. Rolando A. Ibis. 1996, vol. 138, pp. 384-390.

42. Markovets M. Yu. Populyatsionnaya ekologiya gaichki (Parus palustris): avtoref. dis. kand. biol. nauk [Populational ecology of Parus palustris: abstract of candidate's of biological sciences thesis]. Saint-Petersburg: Zool. in-t RAN, 2001, $22 \mathrm{p}$.

43. Bogodyazh O. M. Biologiya belki (Sciurus vulgaris L.) na evropeyskom severo-zapade: avtoref. dis. kand. biol. nauk [Squirrel biology (Sciurus vulgaris L.) in European north-west: abstract of candidate's of biological sciences thesis]. Leningrad: LGU, 1988, 16 p.

44. Inozemtsev A. A. Rol' nasekomoyadnykh ptits $v$ lesnykh biogeotsenozakh [Role of insect-eating birds in forest biogeocenoses]. Leningrad: Izd-vo LGU, 1978, 264 p.

45. Merkova M. A. Byulleten' Moskovskogo obshchestva ispytateley prirody. Otdel biologicheskiy [Bulleting of Moscow Society of Naturalists. Biological Series]. 1955, vol. 60, iss. 1, pp. 21-31.

46. Golikova V. L. Voprosy biogeografii Srednego i Nizhnego Povolzh'ya [Issues on biogeography of Middle and Low Volga Region]. Saratov: Izd-vo Sarat. un-ta, 1968, pp. 267-292.

47. Kutenkov A. P. Melkie mlekopitayushchie zapovednykh territoriy [Small mammals in nature reserve areas]. Moscow: Gl. upr. okhot. khoz-va, 1984, pp. 45-58.

48. Nikitina N. A., Merkova M. A. Byulleten' Moskovskogo obshchestva ispytateley prirody. Otdel biologicheskiy [Bulletin of Moscow Society of Naturalists]. 1963, vol. 68, iss. 5, pp. 15-21.

49. Jaroszewicz B., Piroz nikow E., Sagehorn R. Botany. 2008, vol. 86, pp. 475-484.

50. Malo J. E., Suárez F. Ecography. 1998, vol. 21, pp. 204-211.

51. Korochkina L. N. Belovezhskaya Pushcha [Belavezha Forest]. Minsk: Uradzhay, 1969, pp. $204-221$.

52. Korochkina L. N. Belovezhskaya Pushcha [Belavezha Forest]. Minsk: Uradzhay, 1972, pp. $204-221$.

53. Evstigneev O. I. Mekhanizmy podderzhaniya biologicheskogo raznoobraziya lesnykh biogeotsenozov: dis. $d$-ra biol. nauk [Mechanism of keeping biological diversity of forest biogeocenoses: thesis of doctor of biological sciences]. Nizhniy Novgorod: NNGU im. N. I. Lobachevskogo, 2010, 513 p.

54. Kaletskiy A. A. Biologiya i promysel losya [Biology and cropping of a moose]. Moscow: Rossel'khozizdat, 1965, pp. 113-135.

55. Timofeeva E. K. Los' $^{\prime}$ [Moose]. Leningrad: Izd-vo LGU, 1974, 168 p.

56. Saniga M. Folia Zoologica. 1998, vol. 47 (2), pp. 115-124.

57. Nechaev V. A. Byulleten' Moskovskogo obshchestva ispytateley prirody. Otdel biologicheskiy [Bulletin of Moscow Society of Naturalists]. 2001, vol. 106, iss. 2, pp. 14-21.

58. Bibikov D. I. Tr. Pechorsko-Ylychskogo gosudarstvennogo zapovednika [Proceedings of the Pechora-Ilych State Biosphere Nature Reserve]. Moscow: Glav. upr. po zapovednikam pri SNK RSFSR, 1948, iss. 4, part 2, pp. 89-112.

59. Moskvitin S. S., Ananin A. A., Moskvitina N. S., Nekhoroshev O. G. Puti ratsional'nogo ispol'zovaniya pochvennykh, rastitel'nykh i zhivotnykh resursov Sibiri [Ways of rational use of soil, plant and animal resources in Siberia]. Tomsk: Izd-vo TGU, 1986, pp. 189-191.

60. Evstigneev O. I., Korotkov V. N. Byulleten' Bryanskogo otdeleniya Rossiyskogo botanicheskogo obshchestva [Bulletin of Bryansk branch of Russian Botanical Society]. 2013, no. 1, pp. 31-41.

61. Evstigneev O. I., Pochitaeva M. V., Zhelonkin S. E. Byulleten' Moskovskogo obshchestva ispytateley prirody. Otdel biologicheskiy [Bulletin of Moscow Society of Naturalists. Biological Series]. 1993, vol. 98, iss. 5, pp. 80-87.

62. Smirnova O. V., Voznyak R. R., Evstigneev O. I., Korotkov V. N., Nosach N. Ya., Popadyuk R. V., Samoylenko V. K., Toropova N. A. Botanicheskiy zhurnal [Botanical journal]. 1991, vol. 76, no. 6, pp. 68-79.

63. Evstigneev O. I., Korotkov V. N. Russian Journal of Ecosystem Ecology. 2016, vol. 1 (3), pp. 1-18.

64. Evstigneev O. I., Korotkov V. N., Bakalyna L. V. Byulleten' Moskovskogo obshchestva ispytateley prirody. Otdel biologicheskiy [Bulletin of Moscow Society of Naturalists. Biological Series]. 1992, vol. 97, iss. 2, pp. 81-89. 